\title{
Assessing the feasibility of forest plantation of native species: A case study of Agathis dammara and Eusideroxylon zwageri in Balikpapan, East Kalimantan, Indonesia
}

\author{
BUDI SETIAWAN ${ }^{1,2, \bullet}$, ABUBAKAR M. LAHJIE ${ }^{3, \bullet \bullet}$, SYAHRIR YUSUF $^{3}$, YOSEP RUSLIM $^{3, \bullet \bullet \bullet}$ \\ ${ }^{1}$ Faculty of Forestry, Universitas Tadulako. Jl. Soekarno Hatta Km. 9, Kampus Bumi Tadulako, Tondo, Mantikulore, Palu 94148, Central Sulawesi, \\ Indonesia."email: budimp@untad.ac.id, budi_pascaunmul@yahoo.com \\ ${ }^{2}$ Graduate Program in Forestry, Universitas Mulawarman. Jl. Ki Hajar Dewantara, Gunung Kelua, Samarinda 75123, East Kalimantan, Indonesia \\ ${ }^{3}$ Faculty of Forestry, Universitas Mulawarman. Jl. Ki Hajar Dewantara, Gunung Kelua, Samarinda 75123, East Kalimantan, Indonesia \\ Tel./fax.:+62-541-735379, ${ }^{*}$ email: prof_abudir@yahoo.com; ${ }^{* \bullet}$ yruslim@gmail.com
}

Manuscript received: 2 June 2019. Revision accepted: 8 August 2019

\begin{abstract}
Setiawan B, Lahjie AM, Yusuf S, Ruslim Y. 2019. Assessing the feasibility of forest plantation of native species: A case study of Agathis dammara and Eusideroxylon zwageri in Balikpapan, East Kalimantan, Indonesia. Biodiversitas 20: 2453-2461. Plantation forest using native species is very important effort to support biodiversity conservation. Still, analysis of its feasibility is needed to guarantee sustainable forest management. The research aims were to assess the feasibility of plantation forestry of Agathis dammara and Eusideroxylon zwageri based on production models and financial simulation of stands management. The production models were developed based on plantation forests in Balikpapan, East Kalimantan, Indonesia. Using these plantations we developed models to estimate tree volume, total volume per hectare, Mean Annual Volume Increment (MAI) and Current Annual Increment (CAI) for each species. Financial analyses were carried out to assess the Pay Back Period (PBP), Net Present Value (NPV), Net Benefit/Cost (B/C) Ratio, Internal Rate of Return (IRR) and Equivalent Annual Annuity (EAA). The results of production model showed that $A$. dammara stands would reach optimum production at the age of 25 years while that of E. zwageri at the age of 150 years. A. dammara stands produce higher MAI of $15.67 \mathrm{~m}^{3} \mathrm{ha}^{-1}$ year ${ }^{-1}$ and total volume of $383.72 \mathrm{~m}^{3} \mathrm{ha}^{-1}$ than E. zwageri with MAI $1.89 \mathrm{~m}^{3} \mathrm{ha}^{-1} \mathrm{year}^{-1}$ and total volume of $282.78 \mathrm{~m}^{3} \mathrm{ha}^{-1}$. The result of financial analysis showed that A. dammara plantation had the IRR higher than the Minimum Acceptable Rate (MAR) and the Net B/C Ratio of higher than 1, while E. zwageri had the Net B/C Ratio of lower than 1 . A. dammara plantation also had a positive NPV value of IDR 78,699,974 while E. zwageri plantation had a negative NPV value of IDR 91,439,292. These results suggest that developing A. dammara plantation is more desirable than E. zwageri plantation.
\end{abstract}

Keywords: Agathis dammara, Eusideroxylon zwageri, financial analysis, plantation forest, production model

\section{INTRODUCTION}

Conservation of biodiversity is one of key indicators of the success of sustainable forest management in the future. Biodiversity elements that exist in a forest environment system play important role in developing forest dynamics. However, the conversion of forest land to agriculture and forest plantation using introduced species reduces the extent of primary and secondary forests and threatens biodiversity. In the context of forest plantation, the expansion of plantations becomes problematic, as such several alternatives should be developed in a targeted manner in the hope that it can minimize the impacts on biodiversity (Brockerhoff et al. 2008; Barkin et al. 2013; Dems et al. 2013; Sawada et al. 2016). In some cases, forest plantation using native species within the frame of restoration planting might be required to support biodiversity conservation and to deliver ecosystem services (Budiharta et al. 2014; Budiharta et al. 2018). Therefore, one of the research efforts important to develop is the comparison between managed and not managed forest planting management using native species (Barkin et al 2013; Nouri et al. 2015).
Increasing public knowledge and awareness is needed to achieve the objectives of sustainable forest management. The knowledge includes cost calculations and business analyses that can guarantee the sustainability of the forest itself (Linger 2014; Hartoyo et al. 2016; Muliadi et al. 2017). Good and appropriate development strategies are also required in managing timber harvesting business especially to meet the increasing demand for quality timber while protecting tropical forest diversity (Ruslim 2011; Ruslim et al. 2016).

Economic analysis can be used to compare the productivity between mixed/heterogeneous forest management commonly conducted in tropical region and homogeneous forests plantation using few timber species (Friedrich et al. 2019; Sandalayuk et al. 2019). In order to develop forest management business model, a detailed understanding of all costs incurred in various activities is needed to estimate the financial performance. Financial analysis using different cost assumption will have different implication on the financial results expected in the future, either too high or too low (Barkin et al. 2013; Dems et al. 2013; Callaghan et al. 2019). Information about finance, investment, statistics, and marketing results must be 
combined to obtain a complete comparison. Financial analysis makes it possible to provide a forward-looking picture if a decision will be taken as part of the business risk analysis model plan. Risk analysis can help managers to show the potential financial threats and opportunities in the future whenever there are risks of danger identified so that they can be anticipated in advance (Vavrek 2014; Lahjie et al. 2018a).

Silvicultural activities such as maintenance, thinning and harvesting must be carried out with prudence consideration, not only on technical aspects but also on financial perspectives (Khasanah et al. 2015; Lahjie et al. 2018b). Optimization analysis of forest development must be conducted to assess the uncertainty in stand growth and costs spent during the management regimes from planting to harvesting. This analysis allows to calculate profitable business scale, current net value (NPV) and optimal volume of increment growth (Nghiem and Tran 2016; Soares et al. 2019). Economic valuation is needed to include all important variables so that they can become a reference for further activities (Arias et al. 2011; Price et al. 2011; Latifah and Sulistiyono 2013; Bijalwan 2014).

Forest plantation business has a long period of investment. As such, the longer is the investment period, the interest rate should be lower. In this context, the government needs to adopt a policy that can imply a reduction in interest rates for plantation forestry. Otherwise, problems will arise when the discount rate increases and the investment period will be longer than it should (Price 2011).

Dammar, a natural resin produced from Agathis dammara, became popular since the middle of the 19century in Occident mostly used in art painting materials as final protective coating (varnish) as well as a component of pictorial media. The damar tree A. dammara Lamb is a type of tree member of the conifers (Gymnosperms) which is a native plant of Indonesia. Damar spread across Maluku, Sulawesi, to the Philippines (Palawan and Samar). In Java, this plant is cultivated for the sap or hars. This resin is processed to be copal (Scalarone 2005).

Ulin (Eusideroxylon zwageri Teijsm \& Binn) or also referred to as bulian or ironwood is a woody tree and is a typical plant of Kalimantan. Ulin is a species of native Indonesian tree (indigenous tree species) belong to Lauraceae family. Ulin varieties in West Kalimantan are distinguished based on the use and color of the stem, namely tando ulin with reddish-brown bar, wax ulin with dark brown bar, copper ulin with yellowish stem color and lime ulin with light brown bar. Ironwood, candles, and copper are usually used for building foundations and floors. Lime ulin is the only ironwood that is easily split, making it suitable for raw materials for shingles (Heyne 1987; Yusliansyah et al. 2004). Ulin has an important meaning as one of the endangered native species of Kalimantan which is very slow to grow, but it has a very high economic value. There is growing idea to develop ulin plantations to sustainably manage the species not only to gain the economic benefits, but also as conservation efforts.

The aims of this study were to assess the feasibility of plantation forestry of A. dammara and E. zwageri based on production models and financial simulation of stands management. These were achieved by determining the volume increments of $A$. dammara and $E$. zwageri, finding out the optimum age and maximum increment of both species which meet the wood processing industry requirements, analyzing the financial feasibility of the business of plantation forestry of both species, identifying the rate of interest to be feasible, and knowing the resilience of the plantation forestry using sensitivity analysis.

\section{MATERIALS AND METHODS}

\section{Study area}

This research was carried out in Arboretum Inhutani I area of Balikpapan in Karang Joang Village, Balikpapan City, East Kalimantan Province, Indonesia. The study sites were located at geographical coordinates of $1^{\circ} 11^{\prime} 14.5^{\prime} \mathrm{S}$ - $116^{\circ} 52$ ' 46.6”' E (Figure 1).

\section{Data collection}

The study was conducted for 6 months from May 2018 to October 2018, which included research preparation, primary and secondary data collection, data analysis and preparation of reports. Specifically for preparation and retrieval activities, some secondary data on the general information of the area had been started since April 2018.

\section{Production model}

Table 1 shows that $A$. dammara stand has an age of 31 years. It has planting space of $4 \times 4 \mathrm{~m}$ with a total population of 285 trees. We sampled $20 \%$ of the population, equating to 57 trees. Similarly, E. zwageri stand has an age of 31 years with planting space $4 \times 4 \mathrm{~m}$ and total population of 425 trees. We took 85 trees as a sample, equating to $20 \%$ of the population. Both stands had been planted in the secondary forest owned by Inhutani I company Balikpapan, East Kalimantan since 1987 using system monoculture technique.

Table 1. Production model developed in this study consisting of information on land management with stands composition

\begin{tabular}{lcccc}
\hline Stands & $\begin{array}{c}\text { Spacing } \\
(\mathbf{m})\end{array}$ & $\begin{array}{c}\text { Extent } \\
\left(\mathbf{m}^{\mathbf{2}}\right)\end{array}$ & $\begin{array}{c}\text { Number of } \\
\text { individual (trees) }\end{array}$ & $\begin{array}{c}\text { Number of } \\
\text { sample (20\%) }\end{array}$ \\
\hline Production Model I: Agathis dammara (31 years age) & $4 \times 4$ & 10,000 & 285 & 57 \\
Production Model II: Eusideroxylon zwageri (31 years age) & $4 \times 4$ & 10,000 & 425 & 85 \\
\hline
\end{tabular}



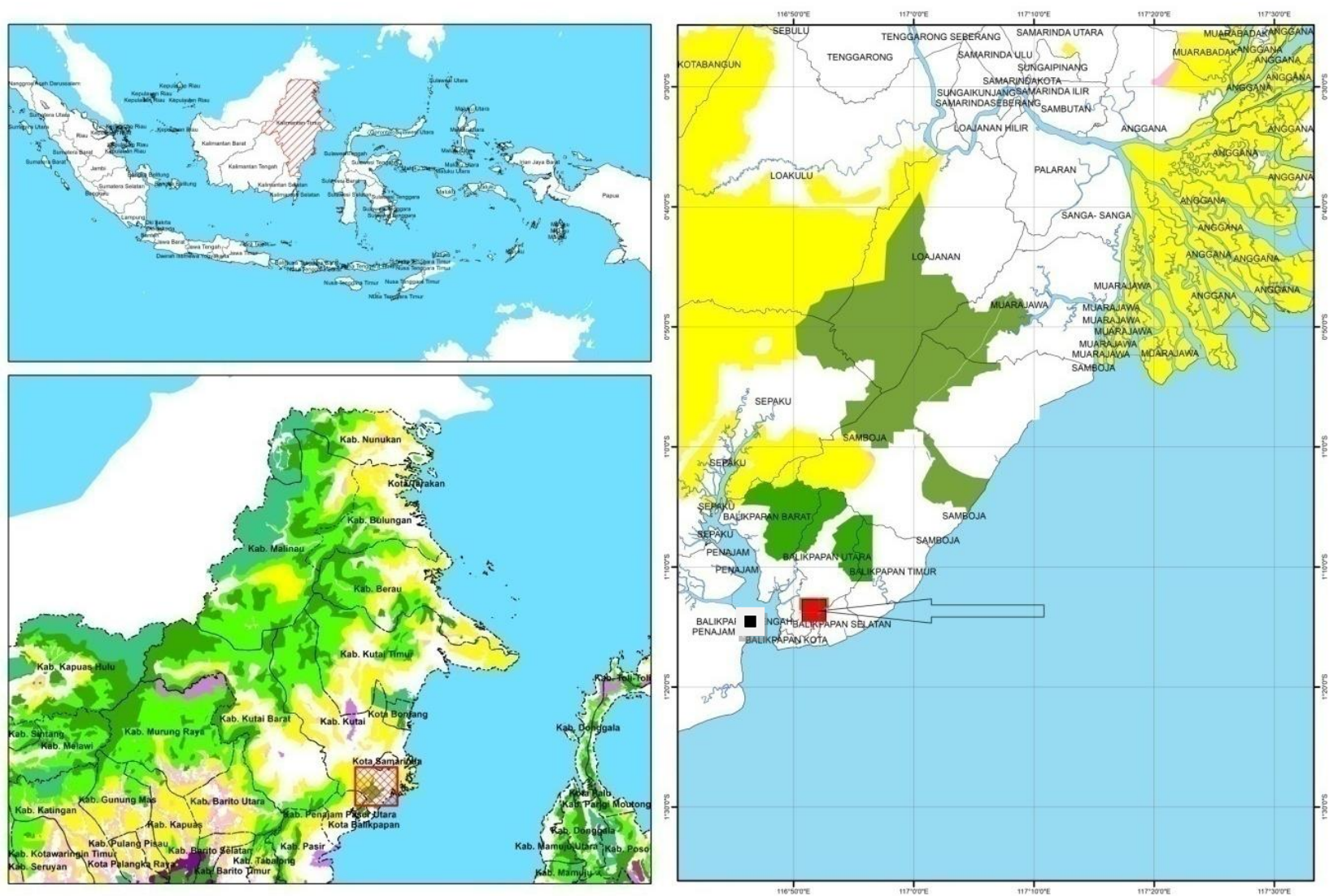

Figure 1. Study sites at Arboretum Inhutani I Km. 10 area of Balikpapan in Karang Joang Village (匹), Balikpapan District, East Kalimantan, Indonesia

\section{Growth and volume analysis}

The variables measured within the plots to obtain estimates of the potential production of A. dammara and $E$. zwageri were as follows: tree volume, total volume per hectare, Mean Annual Volume Increment (MAI), and Current Annual Increment (CAI) (Van Gardingen et al. 2003; Lahjie et al. 2019).

$$
\mathrm{MAI}=\frac{\mathrm{Vt}}{\mathrm{t}}
$$

Where, MAI $=$ Mean Annual Increment $\left(\mathrm{m}^{3} \mathrm{ha}^{-1} \mathrm{year}^{-1}\right)$, $\mathrm{Vt}=$ total volume at age $\mathrm{t}\left(\mathrm{m}^{3} \mathrm{ha}^{-1}\right), \mathrm{t}=$ tree age (in years)

$$
\mathrm{CAI}=\frac{\mathrm{Vt}-\mathrm{Vt}-1}{\mathrm{n}}
$$

Where, CAI $=$ Current Annual Increment $\left(\mathrm{m}^{3} \mathrm{ha}^{-1}\right.$ year $\left.^{-1}\right)$, $\mathrm{Vt}=$ Total volume at age $\mathrm{t}\left(\mathrm{m}^{3} \mathrm{ha}^{-1}\right), \mathrm{V}_{\mathrm{t}-1}=$ Previous total volume $\left(\mathrm{m}^{3} \mathrm{ha}^{-1}\right), \mathrm{T}=$ Second age minus the first age (in years).

Mean Annual Increment increased significantly with increasing spacing while spacing did not have significant effect on total volume production and basal area. Stand density is also not affected by spacing while heartwood proportion increases as planting spacing increases (Zahabu et al. 2015).

\section{Financial analysis}

Based on the data obtained, financial analysis was then performed according to the research objectives. Based on Kadariah (1987), the data analysis criteria used using the calculation formula as follows:

\section{Payback Periods (PP)}

Payback Periods are the period of time required to repay (return) all costs incurred in the investment of a project.

$$
\mathrm{PP}=\frac{\text { Cost of capital invested }}{\text { Average net cost per year }}
$$

\section{Net Benefit Cost Ratio (Net B/C)}

Net $B / C$ is a comparison between the Present Value of a positive Net Benefit (+) and the Present Value of a negative Net Benefit. The mathematical formula of Net B/C can be written as follows (Kadariah 1987):

Net Benefit Cost Ratio $=\frac{\sum \text { Present Value Net Benefit }(+)}{\sum \text { Present Value Net Benefit }(-)}$

Net Benefit Cost Ratio $=\frac{\left[\sum_{\mathrm{t}=1}^{\mathrm{n}} \frac{\mathrm{Bt}-\mathrm{Ct}-\mathrm{Kt}}{(1+\mathrm{i})^{\mathrm{t}}}\right](+)}{\left[\sum_{\mathrm{t}=1}^{\mathrm{n}} \frac{\mathrm{Bt}-\mathrm{Ct}-\mathrm{Kt}}{(1+\mathrm{i})^{\mathrm{t}}}\right](-)}$ 
Where, $\mathrm{Bt}=$ net benefit during the year of operation $\mathrm{t}$, $\mathrm{Ct}=$ net cost in business years $\mathrm{t}, \mathrm{Kt}=$ investment at the beginning of year $0, \mathrm{n}=$ economic age of exploitation time (rotation), $\mathrm{i}=$ applicable interest rate (discount rate).

If Net $\mathrm{B} / \mathrm{C} \geq 1$, then the project is declared to be able to continue or benefit, but if Net $\mathrm{B} / \mathrm{C}<1$, then the project does not provide benefits and should not be attempted.

\section{Net Present Value (NPV) or Net Present Worth (NPW)}

NPV is the difference between Present Value Benefit and Net Present Value of Cost. The formula of NPV can be written as follows (Kadariah 1987):

\section{NPV $=$ Present Value Benefit - Present Value Cost} $(\mathrm{NPV}=\mathrm{B}-\mathrm{C})$

Where, $\mathrm{B}=$ benefits in present value, $\mathrm{C}=$ cost in present value.

The NPV project analysis can be formulated mathematically as follows:

$$
\begin{aligned}
& N P V=-K t \frac{B_{1}-C_{1}}{(1+i)^{t}}+\frac{B_{2}-C_{2}}{(1+i)^{t}} \cdots \cdot \frac{B_{n}-C_{n}}{(1+i)^{n}} \\
& N P V=\left[\sum_{t=1}^{n} \frac{B t-C t-K t}{(1+i)^{t}}\right]
\end{aligned}
$$

Where, $\mathrm{Kt}=$ capital used in the investment period, $\mathrm{B} 1$, $\mathrm{B} 2, \ldots \mathrm{Bn}=$ receipts in the first to ninth years, $\mathrm{C} 1, \mathrm{C} 2, \ldots$ $\mathrm{Cn}=$ expenditures in the 1 st year to the (n)th year, $\mathrm{i}=$ interest rate (discount rate).

If an NPV $\geq 0$ is obtained, the project can be accepted or continued and if NPV $\leq 0$, the project is not feasible.

\section{Internal Rate of Return (IRR)}

IRR is a discount rate that can make the Net Present Value of the project equal to zero $(\mathrm{NPV}=0)$, or can make a Benefit Cost Ratio equal to one $(\mathrm{B} / \mathrm{C}=1)$. The formula in project analysis, IRR can be written as follows (Kadariah 1987):

$$
I R R=\left[i^{\prime}+\frac{N P V^{\prime}}{N P V^{\prime}-N P V^{\prime \prime}}\left(i^{\prime}-i^{\prime \prime}\right)\right]
$$

Where, $\mathrm{i}^{\prime}=$ lowest discount factor, $\mathrm{i}^{\prime}=$ higher discount factor, NPV = Positive Net Present Value (+), NPV" = Negative Net Present Value (-).

If $I R R \geq$ the interest rate of the bank, the project is feasible to be undertaken, whereas if IRR $<$ the prevailing bank interest rate, the project is not feasible.

\section{Equivalent Annual Annuity (EAA)}

EAA is used in determining the scale of land management businesses based on the average needs of household heads per year ( 5 people/head of family) with an average net income per year per hectare which is equivalent in value. The formula used in calculating the EAA as follows (Kadariah 1987):

$$
E A A=N P V \frac{i}{1-(1+i)^{-n}}
$$

Where, $\mathrm{i}=$ interest rate, $\mathrm{n}=$ long of time period.

\section{Sensitivity analysis}

Sensitivity analysis is used to determine the likelihood of the results of the analysis if there are changes or errors in the basics of calculating costs and revenues. These changes or errors will affect the NPV, Net $\mathrm{B} / \mathrm{C}$ ratio, and IRR values. The basics used in sensitivity testing or sensitivity analysis were: (i) The simulation of benefit was decreased by $10 \%$, while other factors were considered constant; (ii) The simulation of costs was increased by $10 \%$, while other factors were considered constant. The simulation of benefit was decreased by $10 \%$, while other factors were considered constant.

\section{RESULTS AND DISCUSSIONS}

\section{Production model \\ Production model I: Agathis dammara}

Agathis dammara stands had spacing of $4 \mathrm{~m} \mathrm{x} 4 \mathrm{~m}$ with planting area of 1 hectare. The number of seedlings planted in the first year was $625 \mathrm{ha}^{-1}$. Measurements of stands were conducted at the age of 2, 4, 8, 10, 15, 20, 25 and 30 years, respectively (Lahjie et al. 2018a). The total population of 31 years stands was $285 \mathrm{ha}^{-1}$ and the sample taken was $20 \%$, equating to $87 \mathrm{in}$. ha ${ }^{-1}$. The estimated stand production cycle was assumed to be 30 years old.

Table 2 shows that the number of stands decreases naturally and as a result of thinning processes as the age of stands increase. Total population of stands at the starting age of 2 years was $580 \mathrm{ha}^{-1}$. According to economically cycle at the harvesting age of 25 years was $340 \mathrm{ha}^{-1}$. The average diameter of stands at the age of 20 to $27.0 \mathrm{~cm}$. The diameter distribution at the age of 25 years ranged between $27 \mathrm{~cm}$ and $36 \mathrm{~cm}$ with the most frequent diameter of 32 $\mathrm{cm}$. Branch free height on average at the age of 20 years was $16.5 \mathrm{~m}$.

The analysis of the Mean Annual Increment (MAI) and the Current Annual Increment (CAI) shows that the lowest difference between both variables (i.e. $0.32 \mathrm{~m}^{3} \mathrm{ha}^{-1}$ year ${ }^{-1}$ ) is achieved at the age of 25 years, implying the optimum age for production cycle. At the age of 25 years, the average volume of each tree was $1.13 \mathrm{~m}^{3}$, the average diameter of each tree was $32.0 \mathrm{~cm}$, the average of branch free height was $18 \mathrm{~m}$, the total stand volume was $383.72 \mathrm{~m}^{3} \mathrm{ha}^{-1}$, while the MAI was $15.35 \mathrm{~m}^{3} \mathrm{ha}^{-1}$ year $^{-1}$ and the CAI was 15.67 $\mathrm{m}^{3} \mathrm{ha}^{-1}$ year ${ }^{-1}$. The reduction in the number of trees increases the MAI to be optimum at the age of 25 years (with $15.35 \mathrm{~m}^{3} \mathrm{ha}^{-1}$ year ${ }^{-1}$ ), but was less influential at later ages, as shown that at the age of 30 years the MAI was slightly increasing to $15.67 \mathrm{~m}^{3} \mathrm{ha}^{-1}$ year ${ }^{-1}$

Figure 2 shows clearly that the intersection point between MAI and CAI which occurs at the age of 25 years. This means that at the age of 25 years, the stands are ready to be harvested with a total production volume of 383.72 $\mathrm{m}^{3} \mathrm{ha}^{-1}$ year $^{-1}$ (Sarjono et al. 2017). 



Figure 2. A. Agathis dammara stands at the age of 31 years with spacing of $4 \mathrm{~m} \mathrm{x} 4 \mathrm{~m}$; and B. Branch free height $(\mathrm{H})$ of tree's dimension

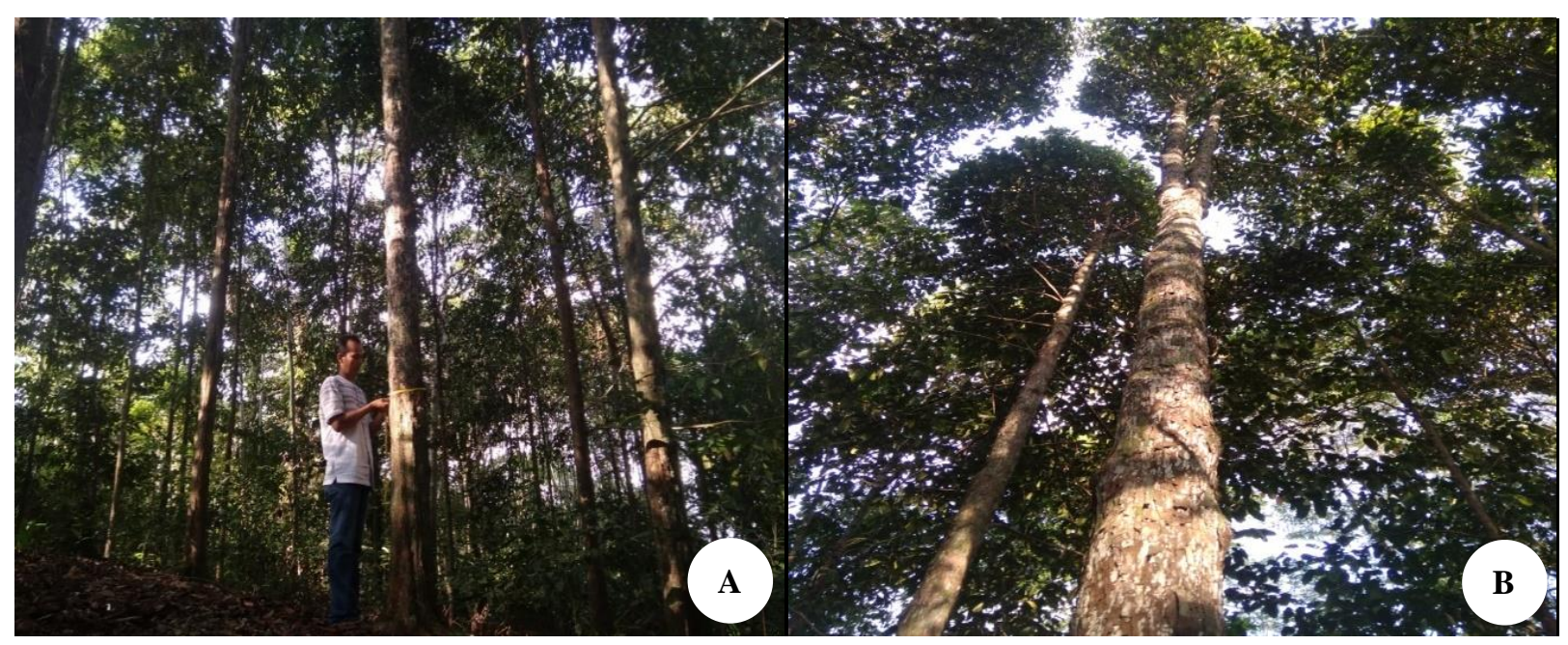

Figure 3. Eusideroxylon zwageri stands at the age of 31 years with spacing of $4 \mathrm{~m} \mathrm{x} 4 \mathrm{~m}$; and B. Branch free height $(\mathrm{H})$ of tree's dimension

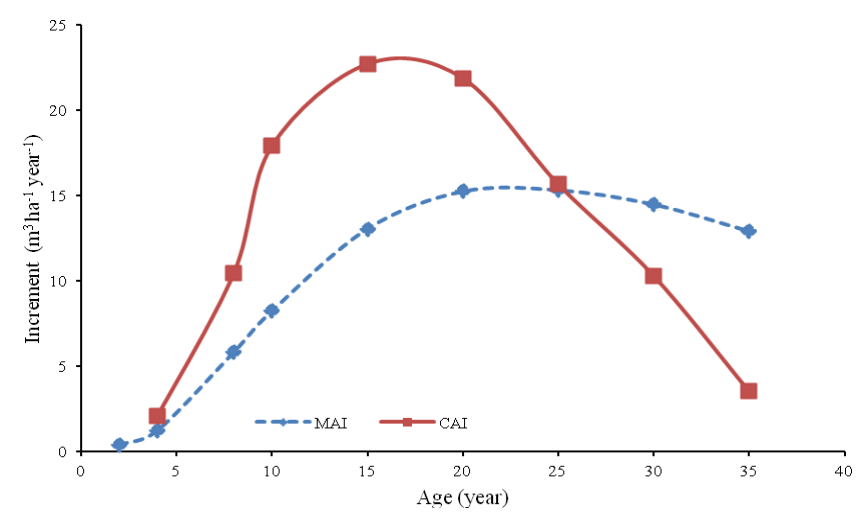

Figure 2. Intersection point between MAI and CAI of Agathis dammara which occurs at the age of 25 years stands

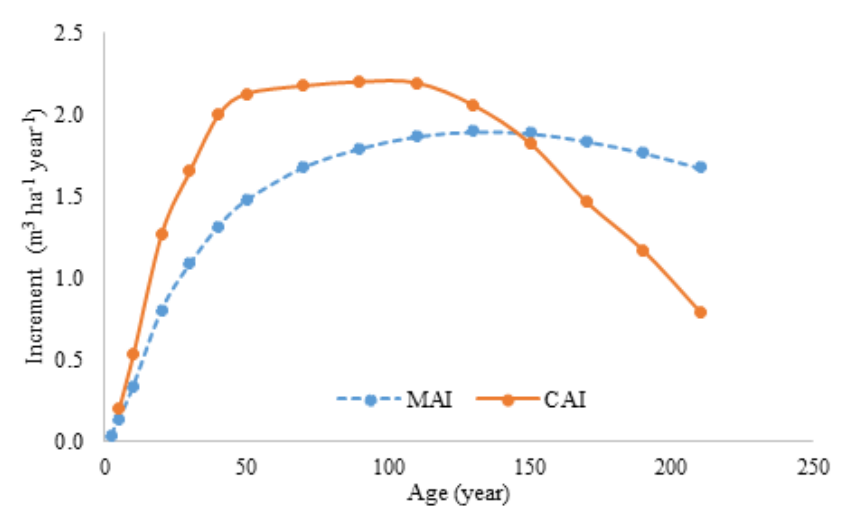

Figure 4. Intersection point between MAI and CAI of Eusideroxylon zwageri which occurs at the age of 150 years stands 
Table 2. Production Model I: Agathis dammara stands with planting spaces of $4 \mathrm{~m} \mathrm{x} 4 \mathrm{~m}$

\begin{tabular}{llllllll}
\hline Ages & $\mathbf{N}$ & $\mathbf{D}$ & $\mathbf{H}$ & $\mathbf{V}$ & $\mathbf{V t}$ & MAI & CAI \\
\hline 2 & 580 & 3.0 & 2.5 & 0.001 & 0.74 & 0.37 & - \\
4 & 560 & 5.5 & 5.0 & 0.009 & 4.85 & 1.21 & 2.06 \\
8 & 540 & 12.5 & 9.5 & 0.086 & 46.56 & 5.82 & 10.43 \\
10 & 520 & 15.5 & 11.2 & 0.158 & 82.38 & 8.24 & 17.91 \\
15 & 490 & 21.5 & 14.5 & 0.400 & 195.94 & 13.06 & 22.71 \\
20 & 420 & 27.0 & 16.5 & 0.727 & 305.37 & 15.27 & 21.89 \\
25 & 340 & 32.0 & 18.0 & 1.129 & 383.72 & 15.35 & 15.67 \\
30 & 285 & 36.0 & 19.0 & 1.527 & 435.21 & 14.51 & 10.30 \\
35 & 240 & 39.5 & 19.5 & 1.887 & 452.83 & 12.94 & 3.52 \\
\hline
\end{tabular}

Note: N: Number of population (trees ha $\left.{ }^{-1}\right)$; D: average tree diameter $(\mathrm{cm})$; H: average branch-free height $(\mathrm{m})$; Vt: total volume per hectare $\left(\mathrm{m}^{3} \mathrm{ha}^{-1}\right)$; MAI: Mean Annual Increment $\left(\mathrm{m}^{3} \mathrm{ha}^{-1}\right.$ year $\left.{ }^{-1}\right)$; CAI: Current Annual Increment $\left(\mathrm{m}^{3} \mathrm{ha}^{-1}\right.$ year $\left.^{-1}\right)$

Table 3. Production Model II: Eusideroxylon zwageri stands with planting spaces of $4 \mathrm{~m} \mathrm{x} 4 \mathrm{~m}$

\begin{tabular}{|c|c|c|c|c|c|c|c|}
\hline Ages & $\mathbf{N}$ & D & $\mathbf{H}$ & $\mathbf{V}$ & $V t$ & MAI & CAI \\
\hline 2 & 590 & 1.3 & 1.2 & 0.000 & 0.08 & 0.04 & - \\
\hline 5 & 550 & 3.1 & 2.1 & 0.001 & 0.69 & 0.14 & 0.20 \\
\hline 10 & 450 & 6.0 & 3.4 & 0.007 & 3.37 & 0.34 & 0.54 \\
\hline 20 & 430 & 12.0 & 4.3 & 0.037 & 16.09 & 0.80 & 1.27 \\
\hline 30 & 425 & 15.3 & 5.5 & 0.077 & 32.65 & 1.09 & 1.66 \\
\hline 40 & 395 & 19.1 & 6.2 & 0.133 & 52.60 & 1.32 & 2.00 \\
\hline 50 & 370 & 22.0 & 7.1 & 0.200 & 73.86 & 1.48 & 2.13 \\
\hline 70 & 360 & 26.5 & 8.1 & 0.326 & 117.35 & 1.68 & 2.17 \\
\hline 90 & 335 & 30.6 & 9.1 & 0.482 & 161.34 & 1.79 & 2.20 \\
\hline 110 & 305 & 34.4 & 10.2 & 0.673 & 205.18 & 1.87 & 2.19 \\
\hline 130 & 270 & 38.5 & 11.2 & 0.912 & 246.30 & 1.89 & 2.06 \\
\hline 150 & 240 & 42.4 & 12.1 & 1.178 & 282.78 & 1.89 & 1.82 \\
\hline 170 & 210 & 45.9 & 13.2 & 1.486 & 312.04 & 1.84 & 1.46 \\
\hline 190 & 180 & 49.8 & 14.3 & 1.863 & 335.39 & 1.77 & 1.17 \\
\hline 210 & 155 & 54.0 & 15.0 & 2.266 & 351.26 & 1.67 & 0.79 \\
\hline
\end{tabular}

Note: N: Number of population (trees $\left.\mathrm{ha}^{-1}\right)$; D: average tree diameter $(\mathrm{cm}) ; \mathrm{H}$ : average branch-free height $(\mathrm{m})$; Vt: total volume per hectare $\left(\mathrm{m}^{3} \mathrm{ha}^{-1}\right)$; MAI: Mean Annual Increment $\left(\mathrm{m}^{3} \mathrm{ha}^{-1}\right.$ year $\left.{ }^{-1}\right)$; CAI: Current Annual Increment $\left(\mathrm{m}^{3} \mathrm{ha}^{-1}\right.$ year $\left.{ }^{-1}\right)$

Production Model II: Eusideroxylon zwageri

Eusideroxylon zwageri stands had planting space of $4 \mathrm{~m}$ $\mathrm{x} 4 \mathrm{~m}$ with a planting area of 1 hectare. The number of seedlings planted in the first year was $625 \mathrm{ha}^{-1}$. Measurements were and will be conducted at the age of 2 , $5,10,20,30,40,50,70,90,110,130,150$ and 210 years, respectively. At the time of this study, the stands were at 31 years old with population of 425 trees $^{-1} \mathrm{~h}^{-1}$ with the sample taken was $20 \%$, equating 85 trees $\mathrm{ha}^{-1}$. The estimated stand production cycle was assumed to be 210 years old.

Table 3 shows that as the stand age increases, the number of stands decreases due to natural processes and as a result of thinning process. The total population of stands at the age of 2 years was $590 \mathrm{ha}^{-1}$, then at the final age of 150 years to $240 \mathrm{ha}^{-1}$. The average diameter of stands according to the measurement age 31 years was to $13.3 \mathrm{~cm}$. The diameter distribution at the age of 25 years ranged between $27 \mathrm{~cm}$ and $36 \mathrm{~cm}$ with the most frequent diameter of $32 \mathrm{~cm}$. Branch free height on average for stands measuring was to $5.5 \mathrm{~cm}$ and for economically cycle at the age of 150 years to $12.1 \mathrm{~m}$.
The result implies the optimum production of stands is achieved at the age of 150 years as at this age the difference between the MAI and the CAI was the lowest (i.e. $0.07 \mathrm{~m}^{3} \mathrm{ha}^{-1}$ year $^{-1}$ ). At this age, the average volume per tree would be $1.178 \mathrm{~m}^{3}$, with average diameter of $42.4 \mathrm{~cm}$ and the branch free height of $12.2 \mathrm{~m}$. The total stand volume at 150 years would be $282.78 \mathrm{~m}^{3} \mathrm{ha}^{-1}$, while the MAI of $1.89 \mathrm{~m}^{3} \mathrm{ha}^{-1}$ year $^{-1}$ and the CAI of $1.82 \mathrm{~m}^{3} \mathrm{ha}^{-1}$ year 1 . The reduction in the number of trees increases the MAI to be optimum at the age of 150 years (with $1.89 \mathrm{~m}^{3} \mathrm{ha}^{-1}$ year $^{-1}$ ), but was less influential at later ages, as shown that at the age of 210 years the MAI was slightly increasing to $1.84 \mathrm{~m}^{3} \mathrm{ha}^{-1}$ year ${ }^{-1}$.

Figure 7 shows clearly that the intersection point between MAI and CAI occurs at the age of 150 years. This means that at the age of 150 years, the stands would ready to be harvested with a total production volume of 282.78 $\mathrm{m}^{3} \mathrm{ha}^{-1}$ year ${ }^{-1}$.

\section{Financial analysis}

In this study, we used the assumption of the price for $A$. dammara was IDR $1,800,000\left(\mathrm{~m}^{3}\right)^{-1}$, while that for $E$. 
zwageri was IDR 7,000,000 $\left(\mathrm{m}^{3}\right)^{-1}$. We simulated financial analysis using varying discount interests for each stand: $5 \%, 10 \%$, and $15 \%$. The harvesting cycle for A. dammara was 25 years, while that of $E$. zwageri was 150 years. Equivalent Annual Annuity (EAA) value was estimated based on the assumption of the total expenditure required for each family to live decently, which was IDR 3,500,000 month ${ }^{-1}$.

\section{Financial analysis of production model I: Agathis} dammara

Table 10 shows that the financial analysis of Production Model I for A. dammara stand with a $5 \%$ interest rate produces an estimated value of the Pay Back Period (PBP) of 10.6 years while the Net Present Value (NPV) of IDR $78,699,974$ with the Net Benefit/Cost (B/C) Ratio of 1.97 , the Internal Rate of Return (IRR) of $8.6 \%$, Equivalent Annual Annuity (EAA) of IDR 5,119,546 and a business scale of 8 ha. Based on these results, it could be concluded that developing plantation forest of $A$. dammara is feasible because it had a positive NPV value and a Net B/C Ratio > 1 , meaning that for each IDR 1 of money invested would return of 1.97 times. This statement is strengthened by the IRR value of $8.6 \%$ which is still greater than the Minimum Acceptable Rate (MAR) value of 5\%. The invested capital would return in the next 10.6 year with a business profit for up to 25 years. The results of the EAA analysis mean that the value of money that could be paid annually is equal to IDR 5,119,546 with an interest rate of 5\%.

\section{Financial analysis of production model II: Eusideroxylon zwageri}

Table 10 shows that the financial analysis of Production Model II for E. zwageri with an interest rate of $5 \%$ results in an estimated 55.1 year of Pay Back Period (PBP) while the Net Present Value (NPV) of IDR -91,439,292, with the Net Benefit/Cost (B/C) Ratio of 0.05, the Internal Rate of Return (IRR) of 13\%, Equivalent Annual Annuity (EAA) of IDR -4,572,127 and business scale of -15 ha. These results suggest that developing $E$. zwageri plantation is not feasible because it had a negative NPV value and Net B/C Ratio $<1$, meaning that for every IDR 1 invested would only return 0.05 times or the capital will not return to normal. This statement is reinforced by the IRR value which is smaller than the Minimum Acceptable Rate (MAR) of 5\%. The invested capital would return in the year 55.1. The negative EAA indicates that the value of money cannot be paid annually in the same amount of IDR $-4,572,127$ with an interest rate of $5 \%$.

\section{Sensitivity analysis of production Model I and Model II using cost raised simulation to $10 \%$}

Table 5 demonstrates that $A$. dammara as Model I had positive NPV by discount factor simulation only to $5 \%$, but negative NPV by discount factor simulation to $10 \%$ and $15 \%$. It is feasible at a discount rate of $5 \%$ with Net $\mathrm{B} / \mathrm{C}$ Ratio of 1.71 , but it is not feasible at a discount rate of $10 \%$ and $15 \%$. E. zwageri as Model II had all negative NPV at all discount rates $(5 \%, 10 \%$, and $15 \%)$. This means that for E. zwageri it needs discount factor of less than $5 \%$. The same result for its Net B/C Ratio which not feasible economically because the result was less than 1 . However, planting E. zwageri might be chosen by farmer for biodiversity conservation reason. Another possible approach is by giving a much higher price for E. zwageri product than the existing price to increase the benefits and to fulfill the need of farmer.

Table 4. The comparison of financial analysis between production Model I and Model II using 5\% interest rate

\begin{tabular}{lcccccccccc}
\hline Stands & $\begin{array}{c}\text { Spacing } \\
(\mathbf{m})\end{array}$ & $\begin{array}{c}\text { Cycle } \\
\text { (years) }\end{array}$ & MAI & $\begin{array}{c}\text { TV } \\
\left(\mathbf{m}^{\mathbf{3}}\right)\end{array}$ & $\begin{array}{c}\text { PP } \\
(\text { year })\end{array}$ & NPV (IDR) & $\begin{array}{c}\text { Net B/C } \\
\text { Ratio }\end{array}$ & IRR (\%) & EAA (IDR) & $\begin{array}{c}\text { Business } \\
\text { scale (ha) }\end{array}$ \\
\hline Agathis dammara & $4 \times 4$ & 25 & 15.67 & 383.72 & 10.6 & $78,699,974$ & 1.97 & $8.6 \%$ & $5,119,546$ & 8 \\
Eusideroxylon zwageri & $4 \times 4$ & 150 & 1.89 & 282.78 & 55.1 & $(120,369,546)$ & 0.02 & $11.9 \%$ & $(6.018 .691)$ & -7 \\
\hline
\end{tabular}

Table 5. The sensitivity analysis of Production Model I and Model II using 5\%, 10\%, and 15\% interest rates and cost raised to $10 \%$

\begin{tabular}{|c|c|c|c|c|c|c|c|}
\hline \multirow{2}{*}{ Stands } & \multicolumn{3}{|c|}{ NPV (x Rp.1000) by discount rate } & \multicolumn{3}{|c|}{ Net $\mathrm{B} / \mathrm{C}$ Ratio by discount rate } & \multirow{2}{*}{$\begin{array}{l}\text { IRR } \\
(\%)\end{array}$} \\
\hline & $5 \%$ & $10 \%$ & $15 \%$ & $5 \%$ & $10 \%$ & $15 \%$ & \\
\hline Agathis dammara & $\begin{array}{c}64,613 \\
(132368)\end{array}$ & $(23,249)$ & $\begin{array}{l}(45,627) \\
(88099)\end{array}$ & $\begin{array}{c}1.72 \\
0.17055\end{array}$ & $\begin{array}{c}0.675 \\
0000179\end{array}$ & $\begin{array}{l}0.25861 \\
0.000004\end{array}$ & 7.9 \\
\hline
\end{tabular}

Table 6. The sensitivity analysis of Production Model I and Model II using 5\%, 10\%, and 15\% interest rates and benefits decrease to $10 \%$.

\begin{tabular}{|c|c|c|c|c|c|c|c|}
\hline \multirow{2}{*}{ Stands } & \multicolumn{3}{|c|}{ NPV (x Rp.1000) } & \multicolumn{3}{|c|}{ Net $B / C$ Ratio } & \multirow{2}{*}{$\begin{array}{l}\text { IRR } \\
(\%)\end{array}$} \\
\hline & $5 \%$ & $10 \%$ & $15 \%$ & $5 \%$ & $10 \%$ & $15 \%$ & \\
\hline Agathis dammara & 56,743 & $(21,767)$ & $(41,690)$ & 1.70 & 0.66 & 0.25 & 7.8 \\
\hline Eusideroxylon zwageri & $(120,370)$ & $(91,379)$ & $(80,090)$ & 0,01677 & 0,00018 & 0,000003 & 10.9 \\
\hline
\end{tabular}




\section{Sensitivity analysis of production Model I and Model II using benefit decreased simulation to $10 \%$}

Table 6 shows the same result as above in which $A$. dammara had a positive NPV value by discount rate $5 \%$, but $E$. zwageri had negative NPV value, moreover if using a discount rate of $10 \%$ and $15 \%$. The slight difference in the case of A. dammara that it is feasible when using a 5\% discount rate, but it is not feasible at $10 \%$ and $15 \%$ discount rate. E. zwageri was not feasible at discount rates of $5 \%, 10 \%$ and $15 \%$ in which resulted in less than 1 of Net B/C Ratio.

In conclusion, Production Model I that estimated the yield of A. dammara plantation is feasible because the IRR value is higher than the Minimum Acceptable Rate (MAR) of $5 \%$ and the Net B/C Ratio is higher than 1. On the other hand, Production Model II that estimated the yield of $E$. zwageri plantation is not feasible because the IRR is lower than MAR of $5 \%$ and the Net B/C Ratio is lower than 1. The optimum period of Production Model I is reached at the age of 25 years while Production Model II would be at the age of 150 years. In A. dammara plantation (Production Model I) will produce higher MAI of $15.67 \mathrm{~m}^{3} \mathrm{ha}^{-1}$ year $^{-1}$ and total volume of $383.72 \mathrm{~m}^{3} \mathrm{ha}^{-1}$ than Production Model II (E. zwageri) with MAI of $1.89 \mathrm{~m}^{3} \mathrm{ha}^{-1}$ year $^{-1}$ and total volume of $282.78 \mathrm{~m}^{3} \mathrm{ha}^{-1}$. The financial analysis demonstrated that Production Model I had a positive NPV value of IDR 78,699,974 while Production Model II had a negative NPV value of IDR 91,439,292. These results suggest that developing A. dammara plantation is more desirable than $E$. zwageri plantation.

\section{ACKNOWLEDGMENTS}

We convey our sincere gratitude and appreciation to all reviewers who gave opinions and final suggestions on the manuscript. Our sincere gratitude and appreciation also go to Aisyah Darmawan and Arnanda, who has helped us in editing and accomplishing this research and Haris Priyana for helping with the study site map. We appreciate and thank to all respondent who gives information data which valuable to completing the research. We would like to thank anonymous reviewers for constructive feedback.

\section{REFERENCES}

Arias D, Calvo-Alvarado J, Richter D de B, Dohrenbusch A. 2011 Productivity, aboveground biomass, nutrient uptake and carbon content in fast-growing tree plantations of native and introduced species in the Southern region of Costa Rica. J Biomass Bioenerg 35 (5): 1779-1788.

Barkin D, Fuente M. 2013. Community forest management: can the green economy contribute to environmental justice? Nat Res Forum 37 (3): 200-210.

Bijalwan A. 2014. A potential fast growing tree for agroforestry and carbon sequestration in India: Anthocephalus cadamba (Roxb.) Miq. J Agric For 2 (6): 296.

Brockerhoff EG, Jactel H, Parrotta JA, Quine CP, Sayer J. 2008 Plantation forests and biodiversity: Oxymoron or opportunity? J Biodivers Conserv 17 (5): 925-951.
Budiharta S, Meijaard, Erskine PD, Rondinini C, Pacifici M, Wilson KA. 2014 Restoring degraded tropical forests for carbon and biodiversity. Env Res Lett 9: 114020

Budiharta S, Meijaard E, Gaveau DLA, Struebig MJ, Wilting A, KramerSchadt S, Niedballa J, Raes N, Maron M., Wilson KA. 2018 Restoration to offset the impacts of developments at a landscape scale reveals opportunities, challenges and tough choices. Glob Environ Change 52, 152-161.

Callaghan D, Khanal P, Straka T, Hagan D. 2019. Influence of forestry practices cost on financial performance of forestry investments. $\mathrm{J}$ Resour 8 (1): 28.

Dems A, Rousseau LM, Frayret, JM. 2013. Effects of different cut-tolength harvesting structures on the economic value of a wood procurement planning problem. J Ann Operations Res 21 (2): 303317.

Friedrich S, Paul C, Brandl S, Biber P, Messerer K Knoke T. 2019. Economic impact of growth effects in mixed stands of Norway spruce and European beech - a simulation based study. J For Pol Econ 104: 65-80.

Hartoyo APP, Siregar IZ, Supriyanto, Prasetyo, LB, Thelaide I. 2016. Biodiversity, carbon stocks and community monitoring in traditional agroforestry practices: Preliminary results from two investigated villages in Berau, East Kalimantan. J Procedia Environ Sci 33: 376385.

Heyne K. 1987. Tumbuhan berguna Indonesia II. Badan Litbang Kehutanan, Forestry Departement, Jakarta. [Indonesian]

Kadariah. 1987. Pengantar Evaluasi Proyek. Fakultas Ekonomi, Universitas Indonesia, Jakarta. [Indonesian]

Khasanah N, Perdana, Rahmanullah A, Manurung G, Roshetko JM, van Noordwijk M. 2015. Intercropping teak (Tectona grandis) and maize (Zea mays): bioeconomic trade-off analysis of agroforestry management practices in Gunungkidul, West Java. Agrofor Syst 89 (6): 1019-1033.

Lahjie AM, Isminarti I, Simarangkir BDAS Kristiningrum R, Ruslim Y. 2018a. Community forest management: comparison of simulated production and financial returns from agarwood, tengkawang and rubber trees in West Kutai, Indonesia. Biodiversitas 19 (1): 126-133.

Lahjie AM, Lepong A, Simarangkir BDAS, Kristiningrum R, Ruslim Y. 2018 b. Financial analysis of dipterocarp log production and rubber production in the forest and land rehabilitation program of Sekolaq Muliaq, West Kutai District, Indonesia. Biodiversitas 19 (3): 707-716.

Lahjie AM, Nouval B, Annisa AL, Ruslim Y, Kristiningrum R. 2019. Economic valuation from direct use of mangrove forest restoration in Balikpapan Bay, East Kalimantan, Indonesia. J F1000 Res.

Latifah S, Sulistiyono N. 2013. Carbon sequestration potential in aboveground biomass of hybrid eucalyptus plantation forest. J Trop For Manag 19 (1): 54-62.

Linger E. 2014. Agro-ecosystem and socio-economic role of homegarden agroforestry in Jabithenan district, North-Western Ethiopia: Implication for climate change adaptation. SpringerPlus 3 (1): 154.

Muliadi M, Lahjie AM, Simarangkir BDAS, Ruslim Y. 2017. Bioeconomic and environmental valuation of dipterocarp estate forest based on local wisdom in Kutai Kartanegara, Indonesia. Biodiversitas 18 (1): 401-408.

Nghiem N, Tran H. 2016. The biodiversity benefits and opportunity costs of plantation forest management: A modelling case study of Pinus radiata in New Zealand. J For 7 (12): 297.

Nouri Z, Zobeiri M, Feghhi J, Amiri GZ, Mohadjer MR. 2015. Comparison of woody species diversity between managed and unmanaged forests considering vertical structure in Hyrcanian forests, Iran. Biodiversitas 16 (1): 95-101.

Price C. 2011. Optimal rotation with declining discount rate. J For Econ 17 (3): 307-318.

Ruslim Y. 2011. Implementing reduced impact logging with mono-cable winch. J Trop For Manag 17 (3): 103-110

Ruslim Y, Sihombing R, Liah Y. 2016. Stand damage due to mono-cable winch and bulldozer yarding in a selectively logged tropical forest. Biodiversitas 17 (1): 222-228.

Sandalayuk D, Lahjie AM, Simarangkir BDAS, Ruslim Y. 2019. Analysis growth and macro elements of Jabon (Anthocephalus cadamba) and Jati (Tectona grandis) in Gorontalo. IOP Conf Ser Earth Environ Sci 270: 012045. DOI: 10.1088/1755-1315/270/1/012045

Sarjono A, Lahjie AM, Simarangkir B.D.A.S, Kristiningrum R, Ruslim Y. 2017. Carbon sequestration and growth of Anthocephalus cadamba 
plantation in North Kalimantan, Indonesia. Biodiversitas 18 (4): 1385-1393.

Sawada Y, Aiba S, Seino T, Kitayama K. 2016. Size structure, growth, and regeneration of tropical conifers along a soil gradient related to altitude and geological substrates on Mount Kinabalu, Borneo. J Plant Soil 403 (1-2): 103-114.

Scalarone D, Duursma MC, Boon JJ, Chiantoire, O. Maldi-Tof. 2005. Mass spectrometry on cellulosic surfaces of fresh and photo-aged diand triterpenoid varnish resins. J Mass Spec 40: 1527-1535.

Soares M, Lahjie AM. 2019. Analisis produksi kayu bulat dan peluang usaha bagi hasil jenis Shorea leprosula dan Shorea smithiana di PT Inhutani I Bukit Bangkirai Balikpapan. J Agrifor 18 (1): 1-12. [Indonesian]

Van Gardingen PR, McLeish MJ, Philips PD, Fadilah D, Tyrie G, Yasman I. 2003. Financial and ecological analysis of management options for logged-over dipterocarp forest in Indonesia Borneo. For Ecol Manag 183: 1-29.

Vavrek PR. 2014. Use of financial analysis in compiling a risk. Management Faculty of Prešov University, Konštantínova, Prešov (2) $127-35$.

Yusliansyah, Effendi E, Ngatiman, Sukanda, Ernayati, Wahyuni, T. 2004. Status litbang ulin (Eusideroxylon zwageri Teisjm \& Binn). Balai Penelitian dan Pengembangan Kehutanan Kalimantan. Samarinda. [Indonesian]

Zahabu E, Raphael, T, Chamshama SAO, Iddi S, Malimbwi RE. 2015. Effect of spacing regimes on growth, yield, and wood properties of Tectona grandis at Longuza forest plantation, Tanzania. Intl J For Res 2015: 469760. DOI: 10.1155/2015/469760. 